\title{
RECOGNITION OF THE GENUS MYRIOPTERIS (PTERIDACEAE, POLY PODIOPSIDA) IN BRAZIL
}

\author{
Vinícius Antonio de Oliveira Dittrich ${ }^{1}$ \& André Luís de Gasper ${ }^{2}$
}

\begin{abstract}
${ }^{1}$ Universidade Federal de Juiz de Fora, ICB, Departamento de Botânica, Rua José Lourenço Kelmer, s.n. - CEP $36036-$ 900, Juiz de Fora, MG, Brazil; vinarc@gmail.com (author for correspondence).

${ }^{2}$ Universidade Regional de Blumenau, Departamento de Ciências Naturais, Rua Antônio da Veiga, 140, CEP 89030903, Blumenau, SC, Brazil.
\end{abstract}

\begin{abstract}
Dittrich, V. A. O. \& A. L. Gasper. 2019. Recognition of the genus Myriopteris (Pteridaceae, Polypodiopsida) in Brazil. Darwiniana, nueva serie 7(1): 137-140.

In the present work, the genus Myriopteris is mentioned for the first time for Brazil, represented by M. myriophylla, a species of wide distribution in the American continent, from Mexico to Argentina, but never before verified for this country. Furthermore, we provide a description of the sole species found, along with an image and notes.
\end{abstract}

Keywords. Brazil; Cheilanthes; cheilanthoid; ferns; taxonomy; Tryonia.

Resumen. Dittrich, V. A. O. \& A. L. Gasper. 2019. Reconocimiento del género Myriopteris (Pteridaceae, Polypodiopsida) en Brasil. Darwiniana, nueva serie 7(1): 137-140.

En el presente trabajo se cita por primera vez al género Myriopteris para Brasil, representado por M. myriophylla, una especie de amplia distribución en el continente americano, desde México hasta la Argentina, pero nunca antes verificada para este país. Se proporciona también una descripción de la única especie representada en el país, además de una imagen y notas.

Palabras clave. Brasil; Cheilanthes; cheilanthoide; helechos; taxonomía; Tryonia.

\section{INTRODUCTION}

Aiming to achieve target 1 of the Global Strategy for Plant Conservation for the year 2020, nearly 700 taxonomists are networking to prepare monographs for the Flora do Brasil (Flora of Brazil) online 2020. This network will make available webpages with descriptions, identification keys, and voucher specimens for all species of plants, algae, and fungi known to that country (BFG - The Brazil Flora Group, 2018).

Alarge number of changes in fern classification have occurred as a result of an avalanche of new phylogenetic information - making it possible to increasingly pursue the recognition of monophyletic families and genera (e.g., PPG I, 2016). Basically, all fern family was revised in light of molecular evidence, and the suborder Pteridineae, in the family Pteridaceae, is one of this. Smith et al. (2006) recognize ca. 50 genera and $950 \mathrm{spp}$., but highlighted that some of the genera were notoriously polyphyletic or paraphyletic and in need of redefinition (e.g., Cheilanthes Sw.). Since then, cheilantoid genera were investigated by several authors (Grusz \& Windham, 2013; Link-Perez et al., 2011; Ponce \& Scataglini, 2018). As a result of the impact of those molecular systematic studies of cheilanthoid ferns, the paraphyly of the globally distributed genus Cheilanthes was demonstrated, 
and others cheilanthoid fern taxa were segregated or recircumscribed into several genera (e.g. Gaga Pryer, F.W. Li \& Windham, Lytoneuron (Klotzsch) Yesilyurt, Calciphilopteris Yesilyurt \& H. Schneid. and Myriopteris Fée). Basically, the specialists in this group of ferns agree that the arid to semiarid conditions where these species grow create a series of adaptive convergences that difficult the genera delimitation.

In the subfamily Cheilanthoideae, PPG 1 (2016) recognized 23 genera and an estimated 426 species. In that context, the resurrected genus Myriopteris stands out as a well-supported monophyletic group comprising approximately $10 \%$ of all cheilanthoid species diversity (Grusz \& Windham, 2013).

Here we provide a new genus record for Brazil, as well as a description of the sole species found, along with an image and notes.

\section{MATERIALS AND METHODS}

Herbarium specimens were consulted at CESJ, RB, FURB, HBR, BHCB, LUSC, CRI, JOI, and MBM (herbarium codes follow Thiers, 2019), as well as the Virtual Herbaria Reflora and INCT, and high-resolution pictures of type collections available from RB (http://jabot.jbrj.gov.br), BR and P(JSTOR, 2018) were consulted. Records of M. myriophylla were obtained from GBIF (2018) and examined for identifications and geographic information.

\section{TAXONOMIC TREATMENT}

Myriopteris Fée, Mém. Foug. 5: 148. 1852. emend. Grusz \& Windham, Phytokeys: 54. 2013. TYPE: Myriopteris marsupianthes Fée, Mém. Foug. 5: 149. 1852.

The genus has its main distribution throughout the American continent, from southern Canada, through the Caribbean and Central America, to southern Chile and Argentina (Mickel \& Smith, 2004; Grusz \& Windham, 2013), and is represented in Africa by a single species endemic to Namibia and South Africa (Grusz \& Windham, 2013). The center of diversity is Mexico, where 34 out of the 44 known species are found, seven of which are endemic (Grusz \& Windham, 2013).
Myriopteris myriophylla (Desv.) Sm., Bot. Voy. Herald: 340. 1856. Cheilanthes myriophylla Desv., Mag. Neuesten Entdeck. Gesammten Naturk. Ges. Naturf. Freunde Berlin 5: 328. 1811. TYPE: Peru. Without date, without collector, (lectotype, inadvertently designated by Tryon \& Stolze, 1989, P00584364!). Fig. 1.

Cheilanthes paleacea M. Martens \& Galeotti, Nouv. Mém. Acad. Roy. Sci. Bruxelles 5(5): 76, t. 21, f. 2. 1842. TYPE: Mexico. Cuesta Blanca, H. Galeotti 6429 (holotype BR000000698439 photo!, isotypes BR0000006982201 photo!, P00584367 photo!).

Plants terrestrial or epipetric. Rhizomes short-creeping, 1.8-3.8 mm thick, scales linearlanceolate, bicolorous, with a black to dark brown central stripe, margins entire, the apex attenuate, sinuous, with a gland. Fronds $24-28 \mathrm{~cm}$ long, stipes ca. $1-2 / 3$ the frond length, tan, terete, covered with appressed pale hairs, laminae 4-pinnate, 9-18 $\times$ 7-9 $\mathrm{cm}$, narrowly lanceolate to triangular, apex pinnatifid, base truncate, ultimate segments beadlike, $0.8-1.4 \times 0.5-0.8 \mathrm{~cm}$, adaxial surface glabrous or with white, simple hairs, abaxial surface densely covered by white to reddish brown triangularlanceolate scales on the rachis, costae, and costules, flexuous hairs present on the abaxial side of the segments, margins strongly recurved, modified into wide false indusia. Sori marginal, sporangia clustered at the vein apices, without paraphyses, covered by false indusia. Spores tetrahedralglobose, surface rugulate.

Distribution and habitat. Mexico, Guatemala, Honduras, El Salvador, Nicaragua, Hispaniola, Colombia, Venezuela, Ecuador, Peru, Brazil, Bolivia, Chile, Argentina, and Uruguay (Mickel \& Smith, 2004; Grusz \& Windham, 2013; Ponce, 2016). The species is widely distributed throughout North, Central, and South America, occupying rather dry, rocky slopes (Mickel \& Smith, 2004). In Brazil, it is currently known only from Santa Catarina State, but its otherwise wide distributed throughout the continent suggests a wider distribution in the country. Both Tryon \& Stolze (1989) and Mickel \& Smith (2004) cited this taxon for Brazil, but no voucher was indicated. 

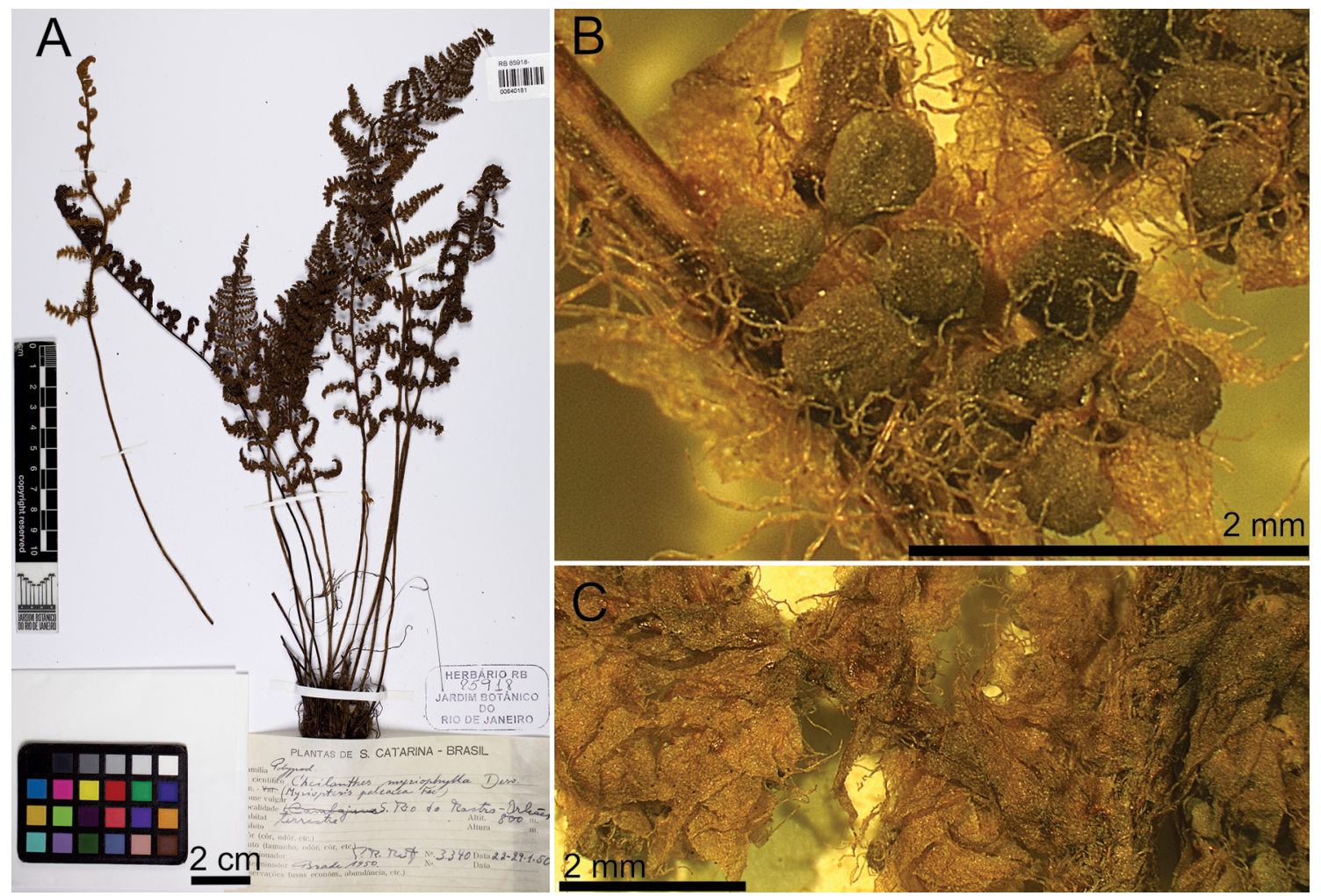

Fig. 1. Myriopteris myriophylla. Reitz 3340 (CESJ, RB). A, habit. B, indusia. C, rachis indument. A from RB. B-C from CESJ. Color version at http://www.ojs.darwin.edu.ar/index.php/darwiniana/article/view/832/1152

Observations. This species can be readily recognized by having a dense covering of scales on the rachis and costae, the ultimate segments beadlike, and by its strongly recurved blade margins, forming wide false indusia.

It is important to note that Myriopteris myriophylla was not cited by Sehnem (1972). Instead he cited Gymnogramma myriophylla Sw. [三 Tryonia myriophylla (Sw.) Schuettp., J.Prado \& A.T.Cochran], specie with which M. myriophylla can be confused, but it is a completely different species, since Myriopteris is clearly distinguishable by its laminar recurved margins and marginal punctual sori, while Tryonia has segments with planar margins, and sori along the veins, among other differences. Also Myriopteris myriophylla can be differentiated from other Cheilanthoideae and Tryonia species in Brazil by its 4-pinnate lamina with bead-like ultimate segments.
Furthermore, Myriopteris produce 64 small or 32 large spores, distinguishing it from Cheilanthes s.s. with 32 small spores (Grusz \& Windham, 2013).

Though many materials were examined in herbaria from south and southeastern Brazil we have failed to find any other specimen of the genus in Brazil. Furthermore, recent collection field trips were done in the same area where R. Reitz collected the plant many years ago, but due to the high anthropogenic effects verified in the area since then, no other specimen was found.

Despite the fact that the authors visited many herbaria - and work in two important ones for Brazilian ferns - only one, old record of the species was found to the country.

\section{Specimens examined}

BRAZIL. Santa Catarina. Orleans, Serra do Rio do Rastro, 800 m, 29-I-1950, R.Reitz 3340 (CESJ, RB, US). 


\section{ACKNOWLEDGEMENTS}

We fully acknowledge Lucas Vieira Lima for all his help with the manuscript.

\section{REFERENCES}

BFG - The Brazil Flora Group. 2018. Brazilian Flora 2020: Innovation and collaboration to meet Target 1 of the Global Strategy for Plant Conservation (GSPC). Rodriguésia 69(4): 1513-1527.

GBIF. 2018. Occurrence Download. Published on the Internet: http:// doi.org/10.15468/dl.ywhpmz [accessed on 22 December 2018].

Grusz, A. L. \& M. D Windham. 2013. Toward a monophyletic Cheilanthes: The resurrection and recircumscription of Myriopteris (Pteridaceae). PhytoKeys 32: 49-64.

JSTOR. 2018. Global Plants on JSTOR. Published on the Internet: http://plants.jstor.org [accessed on 22 December 2018].

Link-Perez, M. A.; L. E. Watson \& R. J. Hickey. 2011. Redefinition of Adiantopsis Fée (Pteridaceae): systematics, diversification, and biogeography. Taxon 60: 1255-1268.

Mickel, J. T. \& A. R. Smith. 2004. The Pteridophytes of Mexico. Memoirs of The New York Botanical Garden 88: 1-1054.
PPG I. 2016. A community-derived classification for extant lycophytes and ferns. Journal of Systematic and Evolution 54: 563-603.

Ponce, M. M. 2016. Subfamilia Cheilanthoideae W.C. Shieh, en F.O. Zuloaga \& M.J. Belgrano (eds.), Flora vascular de la República Argentina 2: 281-316. Instituto de Botánica Darwinion - CONICET.

Ponce, M. M. \& M. A. Scataglini. 2018. Further progress towards the delimitation of Cheilanthes (Cheilanthoideae, Pteridaceae), with emphasis on South American species. Organisms Diversity and Evolution 18: 175-186.

Smith, A. R.; K. M. Pryer, E. Schuettpelz, P. Korall, H. Schneider \& P. G. Wolf. 2006. A classification for extant ferns. Taxon 55: 705-731.

Sehnem, A. 1972. Pteridáceas, en R. Reitz (ed.) Flora Ilustrada Catarinense Fasc. PTER: 1-244. Herbário Barbosa Rodrigues, Itajaí.

Thiers, B. 2019, continuously updated. Index Herbariorum: A global directory of public herbaria and associated staff. New York Botanical Garden's Virtual Herbarium. http:// sweetgum.nybg.org/science/ih/ [accessed on 18 June 2019]

Tryon, R. M. \& R. G. Stolze. 1989. Pteridophyta of Peru. Part II. 13. Pteridaceae - 15. Dennstaedtiaceae. Fieldiana Botany, New Series 22: 1-128. 